This is an electronic reprint of the original article. This reprint may differ from the original in pagination and typographic detail.

Author(s): Hamari, Juho; Nousiainen, Tuula

Title: Why Do Teachers Use Game-Based Learning Technologies? The Role of Individual and Institutional ICT Readiness

Year: $\quad 2015$

Version:

Please cite the original version:

Hamari, J., \& Nousiainen, T. (2015). Why Do Teachers Use Game-Based Learning Technologies? The Role of Individual and Institutional ICT Readiness. In T. X. Bui, \& R. H. Sprague (Eds.), Proceedings of the 48th Hawaii International Conference on System Sciences (HICSS 2015) (pp. 682-691). IEEE. Proceedings of the Annual Hawaii International Conference on System Sciences.

https://doi.org/10.1109/HICSS.2015.88

All material supplied via JYX is protected by copyright and other intellectual property rights, and duplication or sale of all or part of any of the repository collections is not permitted, except that material may be duplicated by you for your research use or educational purposes in electronic or print form. You must obtain permission for any other use. Electronic or print copies may not be offered, whether for sale or otherwise to anyone who is not an authorised user. 
Citation: Hamari, J., \& Nousiainen, T. (2015). Why Do Teachers Use Game-Based Learning Technologies? The Role of Individual and Institutional ICT Readiness. In proceedings of the 48th Annual Hawaii International Conference on System Sciences (HICSS), Hawaii, USA, January 5-8, 2015.

Copyright: (C) 2015 IEEE. Personal use of this material is permitted. Permission from IEEE must be obtained for all other uses, in any current or future media, including reprinting/republishing this material for advertising or promotional purposes, creating new collective works, for resale or redistribution to servers or lists, or reuse of any copyrighted component of this work in other works.

\section{Why Do Teachers Use Game-Based Learning Technologies? The Role of Individual and Institutional ICT Readiness}

\author{
Juho Hamari \\ Game Research Lab \\ University of Tampere \\ juho.hamari@uta.fi
}

\author{
Tuula Nousiainen \\ Agora Center \\ University of Jyväskylä \\ tuula.j.nousiainen@jyu.fi
}

\begin{abstract}
This paper investigates how different individual and institutional factors pertaining to ICT readiness influence teachers' adoption of game-based learning technologies. The data were gathered from Finnish primary, lower secondary and upper secondary school teachers $(N=1668)$ with an online survey. The results indicate that openness towards ICT, ICT attitude and the ICT compatibility with teaching positively influence the perceived value whereas openness towards ICT, supportive organizational ICT culture, ICT selfefficacy and ICT compatibility with teaching positively influenced the actual use of game-based learning technologies. However, the structural model could explain only little of the variance of the dependent variables indicating that these predictors might not be the most relevant factors in the adoption of gamebased learning technologies.
\end{abstract}

\section{Introduction}

During recent years, the use of games has diffused into a variety of areas of everyday life. This development is generally referred to as "gamification" [17][22][23][25][27][39]. In the educational context, also another concept, "game-based learning” (GBL) [44][48][55]), has been established. GBL comprises several approaches to integrating games into teaching and learning. It is most commonly associated with learning games that use "the characteristics of video and computer games to create engaging and immersive learning experiences for delivering specified learning goals, outcomes and experiences” [15]. However, in addition to using these professionally developed learning games that have specific didactic goals, GBL also entails bringing commercial games into the classroom for educational purposes as well as having students design and build their own games [55].

The aim of these developments in educational context is to promote student engagement and consequently positively influence learning outcomes (e.g., [18][48][57]). Recent reviews on empirical studies do indeed indicate that there are positive outcomes to be had from gamification and GBL [14][24]. While game-based technologies are increasingly applied in several areas and games have become one of the main veins of entertainment culture, GBL technologies have been adopted relatively slowly.

Therefore, in this paper we investigate the determinants of adoption and perceived value of GBL among Finnish primary and secondary school teachers via a questionnaire $(n=1668)$. In particular, we focus on how teacher-specific (ICT self-efficacy, ICT attitude, and openness towards ICT) and organizational factors (supportive organizational ICT culture, ICT compatibility with teaching) predict perceived GBL value and GBL adoption.

\section{Theory and hypotheses}

Thus far teacher adoption of technologies has been investigated from a variety of perspectives, such as the goals of the teachers [58], complexity of the technology [3], teacher attitudes [2], educational ideologies [34], an ecological perspective [59], and general technology acceptance (see [49]). However, research on teacher acceptance has shown great variability in results depending on context, technology and types of users (see e.g. [49]). Therefore, peering more deeply into the results in the literature on GBL adoption is important.

The body of research on teachers' views on the use and value of games in the classroom is rapidly expanding but it has been lacking results that are based on large data sets ([29][32] - particularly ones that focus on in-service teachers from across different educational levels. Many studies have collected their data from pre-service teachers (e.g. [31][32][33]), focused on teachers of a certain educational level [9], and limited their scope either on a certain subgroup of games (e.g., commercial games [9]) or virtual worlds rather than games [31][33]. In our study, we address in-service teachers of both primary and secondary school, and we adopt a broad view on GBL, encompassing learning games, commercial games, and game-making [55] but making a distinction between games and virtual worlds. 
Although GBL technologies seem to improve learning outcomes (e.g., [14][24]), teacher adoption of these applications still faces resistance [7][16][33]. The resistance has been mostly attributed to insufficient resources in terms of time and technology as well as teachers' lack of competence and self-efficacy with respect to feasible ways of using GBL technologies (e.g., [7][12][57]). The latter point is related to the notion that games are often still merely associated with play and entertainment while their compatibility with teaching is disregarded - especially by those who have no personal gaming experience and might therefore be less open to experimenting with GBL [12][16][57].

Most earlier studies (e.g. [9][50]) have measured use intention towards different teaching technologies. However, teachers are not always in an autonomous position to adopt these technologies even though they would perceive them as valuable. While we expect value and actual use to be closely related, real-life school contexts present a variety of external factors that either push or restrict the use of certain products (including games). Earlier research suggests that teachers consider external factors to be the primary barrier for technology integration [19]. Therefore, the perceived value of games in education and the extent to which they are actually used by teachers should be examined as two separate constructs.

\subsection{Value and Use of GBL}

As pointed out above, using games for learning is still not a very widespread practice among teachers although teachers typically have more say in the choice of the technologies they use in their work than people in many other occupations [50]. This underscores the importance of understanding the reasons behind the use or non-use of different technologies, such as games, in the classroom. Therefore, we examine the factors that influence whether teachers have introduced GBL into their teaching. We also examine the factors influencing teachers' perceived value of GBL. We define the value to consist of how useful the use of games is perceived to be from the perspective of learning goals and to what extent it is experienced as motivating and engaging [14][18][55][57]. Teachers' intention to use games in their teaching has been found to be profoundly influenced by the degree to which they perceive games as valuable and useful for both learning and productivity [9]. We can hypothesize that:

H1: The perceived value of GBL is positively associated with the use of GBL technology.

The integration of information and communications technology (ICT) into pedagogy in ways that support learning goals is one of the elements of innovative teaching [47]. The adoption of GBL in a meaningful way can be seen as one example of such innovative, ICT-supported teaching, and it can be hypothesized to require certain characteristics and circumstances. These may include such aspects as willingness to explore such an unfamiliar territory, trust in one's own pedagogical and technological competences and abilities, openness to new solutions, as well as an environment that supports and encourages innovative efforts. In the following, we define our core concepts and hypotheses (see Figure 1) related to the factors influencing the adoption of GBL.

\subsection{Openness towards ICT}

Teachers who use ICT in their teaching the most extensively are typically highly motivated to learn and do not consider it a burden when new technological tools are brought into the classroom [41]. Many studies have included the concept of personal innovativeness in the domain of information technology; i.e., a person's willingness to try out any new information technology [1], in their models of technology acceptance. This construct has been shown to play a significant role in technology adoption for pedagogical purposes [28][36][40][53].

In general, games are still considered somewhat of a new and radical form of information technology, which is why it might be difficult for teachers to understand what they are good for, which probably also hinders their adoption (see e.g. [9]). The fact that much of the early research on games focused on their negative impacts (see [14]) may also still cause some concerns about their benefits. Furthermore, games are constantly changing, evolving, and making use of the newest technological advancements, which means that staying on top of what is taking place in the field of gaming requires willingness to explore and experiment [9]. Therefore, a teacher's inclination to experiment with new types of ICT-based tools and practices can be assumed to correlate with her/his willingness to try GBL as well [11]. We hypothesize that:

H2a: Teachers' openness towards ICT is positively associated with the perceived value of GBL.

H2b: Teachers' openness towards ICT is positively associated with the use of GBL technology.

\subsection{Supportive organizational ICT culture}

The results of the international Innovative Teaching and Learning Research (ITL) study [47] show that innovative teaching flourishes in such school environments where there is a collaborative and supportive overall culture particularly in terms of 1) peer support and sharing, 2) teachers' direct involvement in practicing new teaching methods, and 
3) a common vision that encourages novel approaches. Such contextual factors can affect teachers' pedagogical use of ICT [38].

In the case of GBL, social influences have been shown to affect teachers' perceptions of both the usefulness of games for their own work and the learning opportunities that games can provide for their students [9]. Several other studies also emphasize the supportive and encouraging role of the local setting in making the use of games, or other technological interventions, a sustainable classroom practice [8][33][41][51][53]. The aforementioned results lead us to the following hypotheses:

H3a: Supportive organizational ICT culture is positively associated with teachers' perceived value of GBL.

H3b: Supportive organizational ICT culture is positively associated with the teachers' use of GBL technology.

\subsection{Educational ICT self-efficacy}

Among the personal factors influencing teachers' pedagogical use of ICT are their general technical competences as well as their competences in using ICT specifically for pedagogical purposes [38]. The competence aspect is often studied through the concept of self-efficacy, referring to the extent to which an individual believes he/she is able to perform certain actions to achieve specific goals [5].

There is plenty of evidence that having a positive judgment on one's abilities affects the adoption of ICT-based tools and practices in teaching. Firstly, teachers' perceptions of their ability to use computers (i.e., computer self-efficacy) can have an effect on the perceived usefulness and the perceived ease of use of technology, thereby influencing the acceptance of technology [50]. There are also indications that teachers' technology acceptance might be influenced more by their perceived competences related to using a specific technology (i.e., technology self-efficacy) than their perceived competences in using computers in general [26]. For example, a large proportion of teachers completely lack any experience in gaming, which contributes to hindering the use of games in schools [57]. Furthermore, teachers who have positive beliefs in their overall abilities to carry out actions that lead to student learning (i.e., personal teaching efficacy) have more positive attitudes towards adopting new instructional innovations and practices [21]. In the SITES 2006 study, teachers' pedagogical ICT competence was the most significant teacher-related factor influencing the adoption of ICT in education [37]. In the context of this study we hypothesize that:
H4a: Teachers' educational ICT self-efficacy is positively associated with the perceived value of GBL.

H4b: Teachers' educational ICT self-efficacy is positively associated with the use of GBL technology.

\subsection{Attitude towards ICT}

Teachers' attitudes towards technology are one of the strongest determinants of the adoption of ICTbased educational tools and practices [44][51][52][54]. Attitudes are also closely related to teachers' perceptions and beliefs about the extent to which they see ICT as useful and free of effort [50][51]. The role of attitude is especially important with regard to the sustainability of ICT-based pedagogical practices, as positive feelings towards technology are likely to lead to continued use of ICT [50]. In the context of GBL, we can hypothesize that teachers' attitudes towards using technology affect their views on games as well.

H5a: Teachers' positive attitude towards ICT is positively associated with the perceived value of GBL.

H5b: Teachers' positive attitude towards ICT is positively associated with the use of GBL technology.

\subsection{Compatibility of ICT with teaching}

Another factor playing a role in the adoption of new innovations in education is whether they are seen by teachers as practical, compatible with their goals and rationales for using them, and congruent with their present practices and pedagogical beliefs [21][33][37]. In the context of integrating digital games into formal education, teachers' experience and the curriculumrelatedness of the games are particularly crucial in the adoption process [16]. The extent to which teachers consider games to have potential for providing learning opportunities for their students is an important underlying determinant of the adoption of GBL [9][16]. It has been found that teachers' acceptance of technology is influenced also by their perceptions of how useful technology is from the perspective of their own productivity and job performance [50][51][52]. Therefore, we hypothesize that compatibility with teaching (i.e., underlying beliefs, practices, and goals) influences the adoption of games.

H6a: The perceived compatibility of ICT with teaching methods is positively associated with perceived value of GBL.

H6b: The perceived compatibility of ICT with teaching methods is positively associated with the use of GBL technology.

\subsection{Demographic control variables}

In addition to the variables described above, we will examine the relationship between demographic 
variables (age and gender) and the dependent variables with the main purpose of controlling their effects.

2.7.1 Gender. Gender differences have been one topic of interest in the research on technology adoption. Tondeur et al. [53] have found that male teachers integrate ICT in their teaching more often than female teachers when the computer is used as a tool for researching and processing information - which they characterize as the most innovative type of computer use in educational tasks. They suggest that the gender difference in this type of computer use might be related to men being more eager to adopt less familiar computer applications [53]. In their study of parental acceptance of GBL, Bourgonjon et al. [11] discovered that gender differences in experience with games were mediated through innovativeness, which further suggests that males' willingness to adopt games is related to games being a less typical and familiar type of software. A somewhat larger proportion of male than of female teachers have reported playing games for leisure; this could also be reflected in the choices they make with regard to their teaching practices [57].

2.7.2 Age. The effect of age on how teachers use technology has been somewhat ambiguous. In the SITES 2006 study, age was not found to have a significant influence on teachers' use of ICT in education according to the international results [37], but the Finnish results showed that over 50-year-old teachers used less ICT than others [30]. Inan and Lowther [28] found that while age had no significant direct effect on technology integration in the classroom, it influenced technology integration indirectly, mediated by computer proficiency, beliefs, and readiness to integrate technology.

\section{Methods and data}

\subsection{Data and measurement}

The data were gathered from Finnish teachers via an online questionnaire (see Table 1 for demographic information). The survey was distributed by e-mailing the link to the survey to the principals of all primary, lower secondary and upper secondary schools in Finland. The principals further distributed the link to the teachers. The survey was conducted as a collective effort between four projects funded by the Finnish National Board of Education, and the distribution of the survey was facilitated by the Board of Education.

The contents were formulated using the instruments and results of previous large-scale international studies on the educational use of ICT (see e.g. [37][38][47]) and complemented with items based on existing models, other relevant literature, and problems arising from practice. Representatives of educational practice and policy participated in the development of the questionnaire in order to ensure its relevance for practice. The questionnaire was administered in Finnish. Translated items can be found in Appendix A.

Table 1. Gender and age distribution

\begin{tabular}{|l|l|l|l|}
\hline & & Frequency & Percent \\
\hline \multirow{2}{*}{ Gender } & Female & 1247 & 74.8 \\
\cline { 2 - 4 } & Male & 421 & 25.2 \\
\hline \multirow{4}{*}{ Age } & Less than 25 & 7 & 0.5 \\
\cline { 2 - 4 } & $25-35$ & 340 & 20.4 \\
\cline { 2 - 4 } & $35-35$ & 571 & 34.2 \\
\cline { 2 - 4 } & $45-55$ & 554 & 33.2 \\
\cline { 2 - 4 } & More than 55 & 195 & 11.7 \\
\hline
\end{tabular}

\subsection{Validity and reliability}

The descriptive demographic data were analyzed in SPSS 21, and all of the model testing was conducted through partial least squares (PLS) analysis with SmartPLS 2.0 M3 [46]. We tested convergent validity with three metrics: average variance extracted (AVE), composite reliability (CR), and Cronbach's alpha (alpha). All of these values were acceptable (AVE should be greater than 0.5 , CR greater than 0.7 , and Cronbach's alpha above 0.8 - [20] [42]). The construct passed all of the validity and reliability tests.

Discriminant validity was first assessed by comparison of the square root of the AVE of each construct to all correlations between it and other constructs (see [20]), where all of the square roots of the AVEs should be greater than any of the correlations between the corresponding construct and another construct [12]. Secondly, we assessed discriminant validity by confirming that all items corresponding to a specific construct had a higher loading than with any other construct. Thirdly, following Pavlou et al. [43], we determined that no inter-correlation between constructs was more than 0.9 in the correlation matrix (see Table 2). All three tests indicate that the discriminant validity and reliability are acceptable.

The sample size satisfies four different criteria for lower bounds of sample size: 1) "the rule of ten" [42] [6], 2) ten times the largest number of structural paths directed at a particular construct in the inner path model [13], 3) 150 observations for models with three or more indicators on constructs [4], and 4) given the parameters and the effects size in this study, the sample size also satisfies the formula by Westland [56]. However, for the prediction-oriented PLS-SEM, a looser criterion can also be applied: ten times the number of indicators in the most complex construct in the model. Given the measurement model in this paper, the threshold would be 90 respondents. 
Table 2. Convergent and discriminant validity

\begin{tabular}{|c|c|c|c|c|c|c|c|c|c|c|c|c|}
\hline & AVE & CR & Alpha & GBLU & GBLV & SUP & ATT & COM & OPEN & EFF & Gender & Age \\
\hline GBLU & 1.000 & 1.000 & 1.000 & $\mathbf{1 . 0 0 0}$ & & & & & & & & \\
\hline GBLV & 0.888 & 0.941 & 0.874 & 0.312 & $\mathbf{0 . 9 4 2}$ & & & & & & & \\
\hline SUP & 0.660 & 0.906 & 0.871 & 0.174 & 0.092 & $\mathbf{0 . 8 1 2}$ & & & & & & \\
\hline ATT & 0.695 & 0.820 & 0.566 & 0.210 & 0.356 & 0.145 & $\mathbf{0 . 8 3 4}$ & & & & & \\
\hline COM & 0.641 & 0.877 & 0.812 & 0.302 & 0.268 & 0.231 & 0.581 & $\mathbf{0 . 8 0 1}$ & & & & \\
\hline OPEN & 0.655 & 0.792 & 0.474 & 0.318 & 0.243 & 0.191 & 0.463 & 0.550 & $\mathbf{0 . 8 0 9}$ & & & \\
\hline EFF & 0.554 & 0.918 & 0.900 & 0.303 & 0.145 & 0.241 & 0.307 & 0.571 & 0.512 & $\mathbf{0 . 7 4 4}$ & & \\
\hline Gender & 1.000 & 1.000 & 1.000 & -0.037 & 0.094 & 0.021 & -0.054 & 0.043 & 0.020 & 0.200 & $\mathbf{1 . 0 0 0}$ & \\
\hline Age & 1.000 & 1.000 & 1.000 & -0.059 & 0.113 & 0.038 & -0.138 & -0.102 & -0.098 & -0.202 & 0.052 & $\mathbf{1 . 0 0 0}$ \\
\hline $\begin{array}{l}\text { GBLU }= \\
\text { COM }=\text { GBL Use, GBLV = GBL Value, SUP = Supportive organizational ICT culture, ATT = ICT Attitude, }\end{array}$ \\
\hline
\end{tabular}

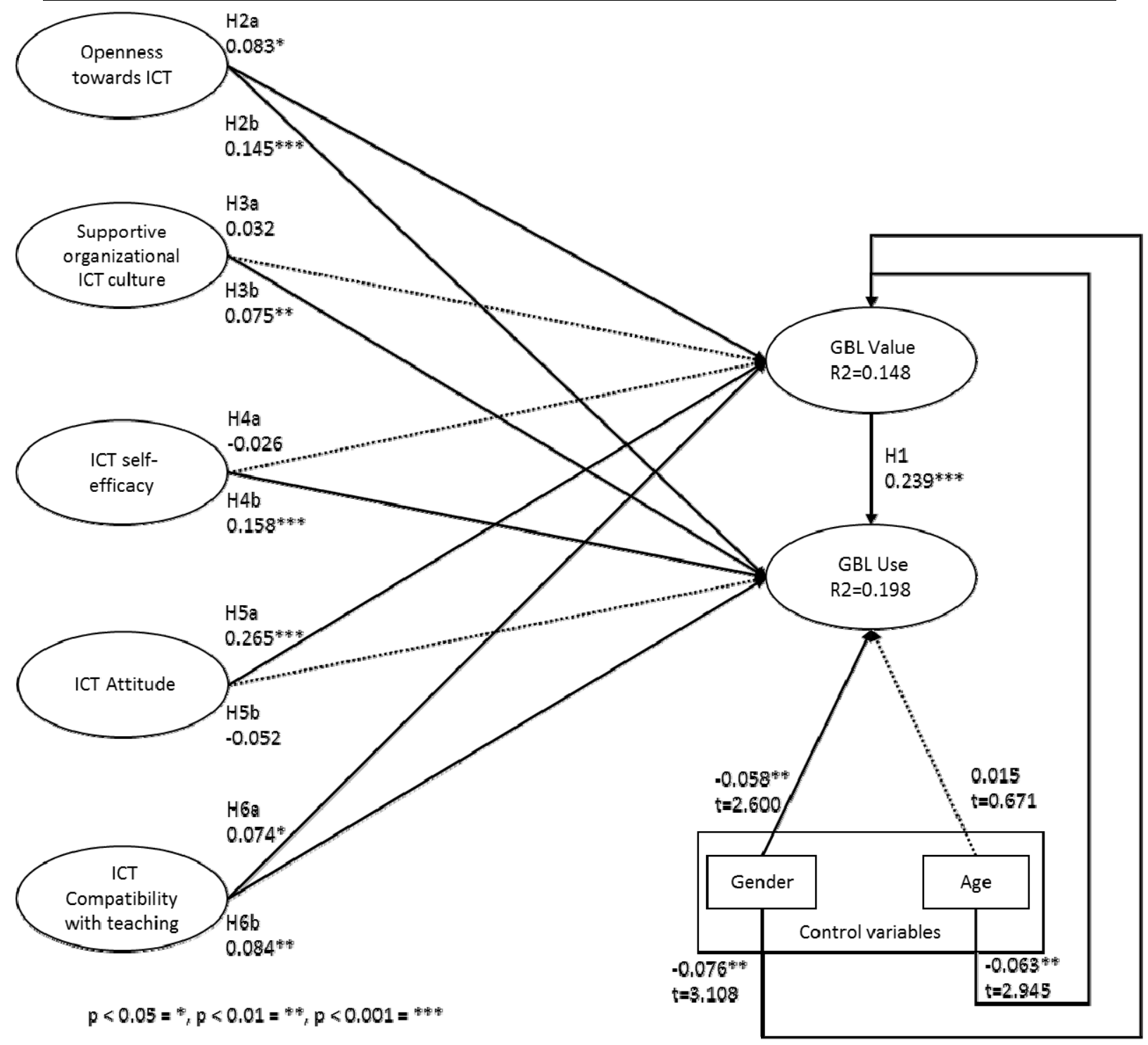

Figure 1: Results 


\section{Results}

The model could account for roughly $15 \%$ of variance of the perceived value of GBL and $20 \%$ of how much the respondent used GBL in their teaching. The results supported most of the hypotheses. The perceived value of GBL was a significant predictor for the use of GBL (H1). Openness towards ICT and perceived compatibility of ICT in teaching (H2a, H2b, $\mathrm{H} 6 \mathrm{a}, \mathrm{H} 6 \mathrm{~b})$ as well as the teacher's gender were significant predictors for both of the dependent variables. Supportive organizational ICT culture (H3b) and self-efficacy (H4b) were a positively associated with actually using GBL, although no significant association to the perceived value could be established (H3a, H4a). ICT attitude and age, on the other hand, had a positive association with GBL value (H5a) but not with the use of GBL in teaching (H5b). Figure 1 depicts the results in more detail.

\section{Discussion}

\subsection{Theoretical and practical contributions and implications}

A certain kind of openness to new ways of working presents itself in the result that teachers who see gamebased innovations as congruent with their teachingrelated goals, beliefs, and practices are more likely to see them as valuable and to take them into use. This might be related to Law and Chow's [37] finding that teachers with a strong orientation towards broad 21stcentury skills are more likely to use ICT than those who are more traditionally oriented. This also supports the finding that constructivist teaching beliefs, as opposed to traditional ones, predict the adoption of ICT in education [53]. Hence, when a teacher's pedagogical beliefs lean more towards cross-curricular and studentcentered approaches, it is plausible that games also fit his or her views and practices better.

The influence of the organizational culture was found to be a significant predictor for GBL use as well. This corresponds to previous findings where innovative teaching practices have been shown to thrive in environments with a collaborative and supportive culture [47]. Interestingly, perceived educational ICT self-efficacy was a significant predictor only for the actual use of GBL, and not for its perceived value. Its positive influence on the actual use of games supports the findings of the international SITES 2006 study on the use of ICT in education [37]. The lack of influence on perceived value could be explained by the notion that people may see technology as valuable even though they do not have the necessary skills and preparedness to use and adopt it, or vice versa. Furthermore, as Holden and Rada [26] suggest, the effect of competence may also depend on whether it refers to the teacher's perceived skills in using ICT in general or in using a specific technology - such as games. In this survey, the efficacy-related questions dealt with ICT in general, not specifically with games. From a practical standpoint, increasing teachers' ICT self-efficacy could help in the adoption of GBL technologies in schools.

While the attitude towards the use of ICTs was a significant predictor for the perceived value of GBL, it did not significantly influence the actual use of games. This may partially have to do with the diverse external factors, such as resources, that come into play in real contexts and affect the adoption or non-adoption of games in practice. Most independent variables investigated in the study can be seen as aspects that are needed in order to use technology. Attitude, however, is not a strict requirement for using technology in the same sense as, for example, ICT self-efficacy. This notion might explain the lack of influence of attitude on GBL use. Attitude was, however, a strong determinant for valuing GBL whereas strict requirements for use, such as self-efficacy, were not. Moreover, attitude only implies a general stance towards something, and in order to translate into action, it may have to be mediated through other, more proactive factors. Finally, the results on the influence of the demographic factors show that gender had a small but significant effect on both the value and the actual use of GBL. Interestingly, in contrast with previous research [11][53][57], female teachers saw GBL as more valuable and also used it more. This finding seems to be aligned with findings in the gamification context [35] where also females have reported to receive more benefits. In order to delve deeper into the reasons for this result, we would have to examine the background of the teachers in more detail to see, for example, if teachers of certain subjects or grade levels had more positive views on games than others and whether the majority of the teachers of these subjects were female.

Age, on the other hand, had a significant effect only on the perceived value, not on the actual use of games. Results related to the effects of age on the use of games, or technology in general, in education have been somewhat contradictory. However, our results are in line with those in the study of Inan and Lowther [28] where the age of the teacher did not directly influence actual technology integration.

Our results suggest certain issues that warrant closer examination and might be important, for example, for planning how to train teachers and promote their interest in the pedagogical use of games. The willingness to adopt games seems to rely heavily on individual factors but, at the same time, a supportive 
social environment can play a significant role in providing encouragement. Thus, we could reason that personalized, one-on-one instruction and guidance from a teacher with effective experiences with GBL would be a viable method for spreading and enhancing the meaningful use of games in teaching. Especially as perceived educational ICT self-efficacy only predicted the actual use of GBL and not its perceived value, teachers who are open to the possibilities of GBL but not confident with their own skills might benefit from such approaches.

\subsection{Limitations and future research}

Further studies could develop more refined multilevel path models on teachers' technology adoption that could also aspire to develop more refined conceptual/theoretical models. For example, the effects of demographic factors (age and gender) might be mediated through other factors such as experience, competences, or innovativeness (e.g., [11][28][37]). Furthermore, as previous research points towards primary educators generally being earlier adopters of games than secondary teachers [45], a more finegrained analysis of potential differences between primary, lower secondary and upper secondary teachers is necessary in order to acquire a more detailed understanding of the issue.

Whereas not so much a limitation of this study, but rather a limitation of the results is that the effect sizes and path coefficient are not very large. Thus, the results hint that although statistically significant, the influences of the independent variables on the dependent variables are rather small. Therefore, clearly, there remain factors that predict teachers' technology adoption that are not measured herein.

\subsection{Conclusion and contribution}

In this paper we examined how various personal and organizational factors affect teachers' perceived value of GBL and their actual use of GBL in their teaching. The data were gathered from Finnish primary, lower secondary and upper secondary school teachers $(\mathrm{N}=1668)$ with an online survey. This study contributes to the area of technology acceptance in general as well as to the vein of literature on why people play games and adopt them. Most particularly, this study sought to make a contribution to the vein of literature on GBL adoption in schools.

In this study, we have attempted to address a gap remaining in the extant literature and build upon earlier exploratory studies (e.g. [33]). Earlier studies on the adoption of games and GBL technologies have focused on parental acceptance of games [11] and perceptions of students on GBL [10]. Earlier studies specifically on teacher adoption and attitudes on GBL learning have presented interesting case studies on the topic that have laid good ground to build on, but have lacked large data sets [29][32]. The only large similar study on GBL adoption is limited to secondary school teachers and to measuring only intentions to adopt GBL [9], while some other studies have focused on virtual world technologies rather than games (e.g., [31]). Bourgonjon et al. [9] focused on a range of rather common factors from e.g. TAM and TPB as well as some domainspecific factors. However, using usefulness (from TAM) as the only mediator between the independent variables and adoption variable prevented inferences between the factors of interest and adoption. Therefore, we opted to explore the direct effects. Moreover, as we theorized, GBL technologies hold interesting domainrelated aspects such as GBLs being perceived as a radical technology that requires strong ICT skills and open mindedness towards technology. Moreover, unlike other technologies it is believed that integrating games into traditional teaching methods poses especial hindrances. Therefore, there is also reason to believe that usefulness might not even mediate these factors but we need further explorative inquiries. Therefore, in this study rather than focusing on a set of variables stemming from a more established theory on technology acceptance and using them strictly as mediators, we opted to focus on factors that we theorized to be of especial importance and have possible more direct effects.

The results contribute the following findings to the theory on teacher adoption of GBL: 1) openness towards ICT, 2) ICT attitude and 3) the ICT compatibility with teaching positively influence the perceived value whereas 4) openness towards ICT, 5) supportive organizational ICT culture, 6) ICT selfefficacy and 7) ICT compatibility with teaching positively influence the actual use of GBL. However, the structural model could explain only little of the variance of the dependent variables indicating that these predictors might not be the most relevant factors in the adoption of GBL and that reasons for adoption should also be sought elsewhere.

\section{Acknowledgements}

This research has been funded by the Finnish Funding Agency for Technology and Innovation (TEKES) and our industry partners. The research was conducted during projects 40311/12, 40134/13, $40111 / 14$ and $40107 / 14$. The data was collected in the projects "Learning games and virtual environments supporting the renewal of teaching and learning" and "Active ICT Usage in Schools", both funded by the Finnish National Board of Education. 


\section{References}

[1] R. Agarwal, and J. Prasad, “A Conceptual and Operational Definition of Personal Innovativeness in the Domain of Information Technology”, Information Systems Research, 9(2), 1998, pp. 204-215.

[2] A. Albirini, "Teachers' attitudes toward information and communication technologies: the case of Syrian EFL teachers”, Computers \& Education, 47(4), 2006, pp. 373-398. [3] R. Aldunate, and M. Nussbaum, "Teacher adoption of technology”, Computers in Human Behavior, 29(3), 2013, pp. 519-524.

[4] J. C. Anderson, and D. W. Gerbing, "The Effect of Sampling Error on Convergence, Improper Solutions, and Goodness of Fit Indices for Maximum Likelihood Confirmatory Factor Analysis”, Psychometrika, 49, 1984, pp. 155-173.

[5] A. Bandura, "Self-efficacy: Toward a Unifying Theory of Behavioral Change”, Psychological Review, 84(2), 1977, pp. 191-215.

[6] D. Barclay, C. Higgins, and R. Thompson, “The Partial Least Squares (PLS) Approach to Causal Modeling: Personal Computer Adoption and Use as an Illustration”, Technology Studies, 2(2), 1995, pp. 285-324.

[7] K. Becker, "Digital Game-Based Learning Once Removed: Teaching Teachers”, British Journal of Educational Technology, 38(3), 2007, pp. 478-488.

[8] K. Becker, and D. M. Jacobsen, "Games for Learning: Are Schools Ready for What's to Come”, Paper presented at the DiGRA 2005 Conference: Changing Views - Worlds in Play, Vancouver, 2005.

[9] J. Bourgonjon, F. De Grove, C. De Smet, J. Van Looy, R. Soetaert, and M. Valcke, "Acceptance of Game-Based Learning by Secondary School Teachers”, Computers \& Education, 67, 2013, pp. 21-35.

[10] J. Bourgonjon, M. Valcke, R. Soetaert, and T. Schellens, "Students' perceptions about the use of video games in education”, Computers \& Education, 54(4), 2010, pp. 11451156.

[11] J. Bourgonjon, M. Valcke, R. Soetaert, B. de Wever, and T. Schellens, "Parental Acceptance of Digital Game-Based Learning”, Computers \& Education, 57(1), 2011, pp. 1434 1444.

[12] W. W. Chin, “The Partial Least Squares Approach for Structural Equation Modeling”, In G. A. Marcoulides, (Ed.), Modern Methods for Business Research, Lawrence Erlbaum Associates, London, 1998, pp. 295-336.

[13] W. W. Chin, and P. R. Newsted, "Structural Equation Modeling Analysis with Small Samples Using Partial Least Squares”, In R. H. Hoyle (Ed.), Statistical Strategies for Small Sample Research, Sage, Thousand Oaks, 1999, pp. 307-342.

[14] T. M. Connolly, E. A. Boyle, E. MacArthur, T. Hainey, and J. M. Boyle, "A Systematic Literature Review of Empirical Evidence on Computer Games and Serious Games”, Computers \& Education, 59(2), 2012, pp. 661-686.

[15] S. De Freitas, Learning in Immersive Worlds: A Review of Game-Based Learning, Joint Information Systems Committee, London, 2006.

[16] F. De Grove, J. Bourgonjon, and J. Van Looy, “Digital Games in the Classroom? A Contextual Approach to Teachers' Adoption Intention of Digital Games in Formal
Education, Computers in Human Behavior, 28(6), 2012, pp. 2023-2033.

[17] S. Deterding, D. Dixon, R. Khaled, and L. Nacke, "From Game Design Elements to Gamefulness: Defining

Gamification”, In Proceedings of the 15th International

Academic MindTrek Conference: Envisioning Future Media

Environments, September 28-30, 2011, Tampere, Finland,

ACM, pp. 9-15.

[18] S. Egenfeldt-Nielsen, "Third Generation Educational Use of Computer Games”, Journal of Educational Multimedia and Hypermedia, 16(3), 2007, 263-281.

[19] P. A. Ertmer, A. T. Ottenbreit-Leftwich, O. Sadik, E. Sendurud, and P. Sendurur, "Teacher Beliefs and Technology Integration Practices: A Critical Relationship”, Computers \& Education, 59(2), 2012, 423-435.

[20] C. Fornell, and D. Larcker, "Structural Equation Models with Unobservable Variables and Measurement Error”, Journal of Marketing Research, 18(1), 1981, pp. 39-50.

[21] G. Ghaith, and H. Yaghi, "Relationships among Experience, Teacher Efficacy, and Attitudes toward the Implementation of Instructional Innovation”, Teaching and Teacher Education, 13(4), 1997, pp. 451-458.

[22] J. Hamari, "Transforming Homo Economicus into Homo Ludens: A Field Experiment on Gamification in a Utilitarian Peer-To-Peer Trading Service”, Electronic Commerce Research and Applications, 12(4), 2013, pp. 236245.

[23] J. Hamari, K. Huotari, and J. Tolvainen. "Gamification and Economics", In S. P. Walz \& S. Deterding (Eds.), The Gameful World: Approaches, Issues, Applications. Cambridge, MA: MIT Press, 2014.

[24] J. Hamari, J. Koivisto, and H. Sarsa, "Does Gamification Work? - A Literature Review of Empirical Studies on Gamification”, In proceedings of the 47th Hawaii International Conference on System Sciences, Hawaii, USA, January 6-9, 2014.

[25] J. Hamari, and V. Lehdonvirta, "Game design as marketing: How game mechanics create demand for virtual goods”, International journal of business science and applied management, 5(1), 2010, pp. 14-29.

[26] H. Holden, and R. Rada, "Understanding the Influence of Perceived Usability and Technology Self-Efficacy on Teachers' Technology Acceptance”, Journal of Research on Technology in Education, 43(4), 2011, pp. 343-367.

[27] K. Huotari, and J. Hamari, "Defining Gamification: a Service Marketing Perspective”, In Proceedings of the 16th International Academic MindTrek Conference, October 3-5, 2012, Tampere, Finland, ACM, pp. 17-22.

[28] F. A. Inan, and D. L. Lowther, "Factors Affecting Technology Integration in K-12 Classrooms: a Path Model”, Educational Technology Research and Development, 58(2), 2010, pp. 137-154.

[29] J. G. Jones, B. Copeland, and K. E. Kalinowski, "Preservice Teachers' Attitudes towards Computer Games”, Paper presented at the AERA annual meeting, Chicago, 2007.

[30] M. Kankaanranta, and E. Puhakka, Kohti innovatiivista tietotekniikan opetuskäyttöä. Kansainvälisen SITES 2006 tutkimuksen tuloksia, Koulutuksen tutkimuslaitos, Jyväskylän yliopisto, 2008. 
[31] S. Kennedy-Clark, "Pre-service Teachers' Perspectives on Using Scenario-based Virtual Worlds in Science Education”, Computers \& Education, 57(4), 2011, pp. 22242235.

[32] R. F. Kenny, and R. McDaniel, “The Role Teachers' Expectations and Value Assessments of Video Games Play in their Adopting and Integrating them into their Classrooms”, British Journal of Educational Technology, 42(2), 2011, pp. 197-213.

[33] D. J. Ketelhut, and C. C. Schifter, “Teachers and GameBased Learning: Improving Understanding of How to Increase Efficacy of Adoption”, Computers \& Education, 56(2), 2011, pp. 539-546.

[34] E. Kiraz, and D. Ozdemir, "The Relationship between Educational Ideologies and Technology Acceptance in Preservice Teachers”, Educational Technology \& Society, 9(2), 2006, pp. 152-165.

[35] J. Koivisto, and J. Hamari, ”Demographic differences in perceived benefits from gamification", Computers in Human Behavior, 35, 2014, pp. 179-188.

[36] H.-M. Lai, and C.-P. Chen, "Factors Influencing Secondary School Teachers' Adoption of Teaching Blogs", Computers \& Education, 56(4), 2011, pp. 948-960.

[37] N. Law, and A. Chow, "Teacher Characteristics, Contextual Factors, and How These Affect the Pedagogical Use of ICT”, In N. Law, W. Pelgrum, and T. Plomp, (Eds.), Pedagogy and ICT Use in Schools Around the World. Findings from the IEA SITES 2006 Study, CERC and Springer, Hong Kong, 2008, pp. 181-219.

[38] N. Law, and A. Chow, "Teacher Questionnaire Development”, In R. Carstens, and W. J. Pelgrum, (Eds.), Second Information Technology in Education Study: SITES 2006 Technical Report. IEA, Amsterdam, 2009, pp. 29-40.

[39] J. J. Lee, and J. Hammer, "Gamification in Education: What, How, Why Bother?”, Academic Exchange Quarterly, 15(2), 2011.

[40] Y. Liu, H. Li, and C. Carlsson, "Factors Driving the Adoption of m-Learning: An Empirical Study”, Computers \& Education, 55(3), 2010, pp. 1211-1219.

[41] I. Mikkonen, H. Sairanen, M. Kankaanranta, and A.-M. Laattala, “Tieto- ja viestintäteknisten laitteistojen ja ohjelmistojen käyttö opetuksessa”. In M. Kankaanranta, I. Mikkonen, and K. Vähähyyppä, (Eds.), Tutkittua tietoa oppimisympäristöistä: Tieto- ja viestintätekniikan käyttö opetuksessa. Opetushallitus, Helsinki, 2012, pp. 9-19.

[42] J. C. Nunnally, Psychometric Theory (2nd ed.). McGraw-Hill, New York, 1978).

[43] P. A. Pavlou, H. G. Liang, and Y. J. Xue, "Understanding and Mitigating Uncertainty in Online Exchange Relationships: A Principal-Agent Perspective”, MIS Quarterly, 31(1), 2007, pp. 105-136.

[44] M. Prensky, Digital Game-Based Learning, Paragon House, St. Paul, 2007.
[45] M. D. Proctor, and Y. Marks, “A Survey of Exemplar Teachers' Perceptions, Use, and Access of Computer-based Games and Technology for Classroom Instruction”, Computers \& Education, 62, 2013, 171-180.

[46] C. M. Ringle, S. Wende, and A. Will, SmartPLS 2.0 M3, http://www.smartpls.de, 2005.

[47] L. Shear, L. Gallagher, and D. Patel, ITL Research 2011 Findings: Evolving Educational Ecosystems, SRI International, 2011.

[48] D.F. Shernoff, J. Hamari, and \& E. Rowe, "Measuring Flow in Educational Games \& Gamified Learning Environments." In Proceedings of EDMedia World Conference on Educational Media and Technology, Tampere, Finland, June 23-26, 2014, 2014.

[49] B. Sumak, M. Hericko, and M. Pusnik, "A Metaanalysis of e-Learning Technology Acceptance: The Role of User Types and e-Learning Technology Types”, Computers in Human Behavior, 27(6), 2011, pp. 2067-2077.

[50] T. Teo, "Modelling Technology Acceptance in Education: A Study of Pre-Service Teachers”, Computers \& Education, 52(2), 2009, pp. 302-312.

[51] T. Teo, "Factors Influencing Teachers' Intention to Use Technology: Model Development and Test”, Computers \& Education, 57(4), 2011, pp. 2432-2440.

[52] T. Teo, and P. van Schalk, "Understanding Technology Acceptance in Pre-Service Teachers: A Structural-Equation Modeling Approach”, The Asia-Pacific Education Researcher, 18(1), 2009, pp. 47-66.

[53] J. Tondeur, M. Valcke, and J. Van Braak, “A Multidimensional Approach to Determinants of Computer Use in Primary Education: Teacher and School Characteristics", Journal of Computer Assisted Learning, 24(6), 2008, pp. 494-506.

[54] F. van Acker, H. van Buuren, K. Kreijns, and M. Vermeulen, "Why Teachers Use Digital Learning Materials: The role of Self-efficacy, Subjective Norm and Attitude", Education and Information Technologies, 18(3), 2013, pp. 495-514.

[55] R. Van Eck, "Digital Game- Based Learning: It’s Not Just the Digital Natives Who Are Restless”, EDUCAUSE Review, 41(2), 2006, pp. 16-30.

[56] C. J. Westland, "Lower Bounds on Sample Size in Structural Equation Modelling”, Electronic Commerce Research and Applications, 9(6), 20210, pp. 476-487.

[57] B. Williamson, Computer games, schools, and young people. A report for educators on using games for learning, Futurelab, Bristol, 2009.

[58] Y. Zhao, and G. A. Cziko, "Teacher adoption of technology: A perceptual control theory perspective”, Journal of Technology and Teacher Education, 9(1), 2001, pp. 5-30.

[59] Y. Zhao, and K. A. Frank, "Factors affecting technology uses in schools: An ecological perspective”, American Educational Research Journal, 40(4), 2003, pp. 807-840. 


\section{Appendix A: The instrument}

\begin{tabular}{|c|c|c|}
\hline Text & Loading & Related literature \\
\hline \multicolumn{2}{|l|}{ Openness towards ICT } & \multirow{3}{*}{$\begin{array}{l}\text { E.g., Agarwal and } \\
\text { Prasad, 1998; Lai and } \\
\text { Chen, 2011; Liu et } \\
\text { al., 2010; Tondeur et } \\
\text { al., 2008 }\end{array}$} \\
\hline I often experiment with new things in my classes. & 0.804 & \\
\hline Constantly bringing new technology into teaching is burdensome. (Reversed) & 0.815 & \\
\hline \multicolumn{2}{|l|}{ Supportive organizational ICT culture } & \multirow{6}{*}{$\begin{array}{l}\text { ITL Research (Shear } \\
\text { et al., 2011), SITES } \\
\text { 2006 (see e.g. Law \& } \\
\text { Chow, 2009) }\end{array}$} \\
\hline The school staff has a collective vision of the use of ICT in education. & 0.664 & \\
\hline Experiences on the use of ICT are shared sufficiently within my work community. & 0.817 & \\
\hline I get good tips from other teachers on how to use ICT in my teaching. & 0.848 & \\
\hline I get support from other teachers for my practices of using ICT in education. & 0.858 & \\
\hline $\begin{array}{l}\text { I get support from other teachers for disseminating my practices of using ICT in education } \\
\text { within my work community. }\end{array}$ & 0.860 & \\
\hline \multicolumn{2}{|l|}{ Educational ICT self-efficacy } & \multirow{10}{*}{$\begin{array}{l}\text { ITL Research (Shear } \\
\text { et al., 2011); SITES } \\
\text { 2006 (see e.g. Law \& } \\
\text { Chow, 2009) }\end{array}$} \\
\hline I can prepare lessons that involve the use of ICT by students. & 0.825 & \\
\hline I know which teaching/learning situations are suitable for ICT use. & 0.785 & \\
\hline I can find useful curriculum resources on the Internet. & 0.704 & \\
\hline I can use ICT to give effective presentations/explanations. & 0.729 & \\
\hline I can install educational software on my computer. & 0.700 & \\
\hline $\begin{array}{l}\text { I can use the Internet (e.g., select suitable websites, user groups/discussion forums) to } \\
\text { support student learning. }\end{array}$ & 0.723 & \\
\hline I have the skills to create new practices for using ICT in education. & 0.801 & \\
\hline Evaluate your technical ICT skills on a scale of 4 to 10 . & 0.682 & \\
\hline Evaluate your pedagogical ICT skills on a scale of 4 to 10 . & 0.739 & \\
\hline \multicolumn{2}{|l|}{ Attitude towards ICTs } & \multirow{3}{*}{$\begin{array}{l}\text { E.g., Teo, 2011; Teo } \\
\text { and van Schalk, } 2009\end{array}$} \\
\hline With the aid of ICT, students are able to process the subjects in diverse ways. & 0.874 & \\
\hline I would not want to use more ICT in my teaching. (Reversed) & 0.781 & \\
\hline \multicolumn{2}{|l|}{ Perceived compatibility of ICT with teaching } & \multirow{5}{*}{$\begin{array}{l}\text { E.g., Ghaith and } \\
\text { Yaghi, 1997; } \\
\text { Ketelhut and Schifter, } \\
\text { 2011; Law and } \\
\text { Chow, } 2009\end{array}$} \\
\hline The use of ICT fits my style of teaching. & 0.812 & \\
\hline I use ICT so that the students would learn to use modern technology. & 0.715 & \\
\hline In my classes, ICT supports the teaching of the content. & 0.826 & \\
\hline ICT supports achieving the teaching goals. & 0.844 & \\
\hline \multicolumn{2}{|l|}{ GBL Use } & \multirow{2}{*}{$\begin{array}{l}\text { SITES } 2006 \text { (see e.g. } \\
\text { Law \& Chow, 2009) }\end{array}$} \\
\hline How often do you use digital learning games? & 1 & \\
\hline \multicolumn{2}{|l|}{ GBL Value } & \multirow{3}{*}{$\begin{array}{l}\text { E.g., Connolly et al., } \\
\text { 2012; De Freitas, } \\
\text { 2006; Williamson, } \\
2009\end{array}$} \\
\hline $\begin{array}{l}\text { On a scale of } 1 \text { to } 10 \text {, how useful do you consider the use of computer games for } \\
\text { educational purposes? }\end{array}$ & 0.949 & \\
\hline $\begin{array}{l}\text { On a scale of } 1 \text { to } 10 \text {, how motivating do you consider the use of computer games for } \\
\text { educational purposes? }\end{array}$ & 0.935 & \\
\hline
\end{tabular}


